\author{
NBER WORKING PAPER SERIES \\ ON \\ HISTORICAL FACTORS IN LONG RUN GROWTH
}

\title{
SHORT-TERM LOANS AND LONG-TERM RELATIONSHIPS: \\ RELATIONSHIP LENDING IN EARLY AMERICA
}

\author{
Howard Bodenhorn
}

Historical Paper 137

\author{
NATIONAL BUREAU OF ECONOMIC RESEARCH \\ 1050 Massachusetts Avenue \\ Cambridge, MA 02138 \\ December 2001
}

The views expressed herein are those of the author and not necessarily those of the National Bureau of Economic Research.

(C) 2001 by Howard Bodenhorn. All rights reserved. Short sections of text, not to exceed two paragraphs, may be quoted without explicit permission provided that full credit, including (C) notice, is given to the source. 
Short-Term Loans and Long-Term Relationships:

Relationship Lending in Early America

Howard Bodenhorn

NBER Historical Paper No. 137

December 2001

JEL No. N2, G2

Development of the American Economy

\begin{abstract}
$\underline{\text { ABSTRACT }}$
Recent banking theory holds that durable firm-bank relationships are valuable to both parties. Using contract-specific loan records of a nineteenth-century U.S. bank, this paper shows that firms that form extended relationships with banks receive three principal benefits. First, firms with extended relationships face lower credit costs. As the bank-borrower relationship matures credit costs decline. Second, long-term customers are asked to provide fewer personal guarantees. Thirdparty guarantees are an efficient alternative to collateral in certain circumstances, and long-term clients are asked to provide fewer guarantees. Third, long-term bank customers more likely to have loan terms renegotiated during a credit crunch. Firms without access to public debt markets rely on bank credit, and continued access during a credit crunch is important for small, informationally opaque firms.
\end{abstract}

\author{
Howard Bodenhorn \\ Department of Economics \\ Lafayette College \\ Easton, PA 18042 \\ and NBER
}




\section{Short-Term Loans and Long-Term Relationships: \\ Relationship Lending in Early America}

Financial institutions provide most external debt financing for small businesses. Approximately 50 percent of small business finance is owner-supplied equity, another 5 percent is owner-supplied debt, about 15 percent is trade credit, and 25 percent is borrowed from financial intermediaries, principally banks (Berger and Udell 1998). Thus for most small businesses banks loom large. In fact, modern theories of financial intermediation view intermediaries as delegated monitors and are mostly theories about funding small, informationally opaque firms (Diamond 1984; Ramakrishan and Thakor 1984). To deal with information and incentive problems surrounding small business finance, intermediaries use collateral, personal guarantees, and foster long-term relationships with borrowers.

Both practicing bankers and economic theorists have long argued that bank relationships are valuable. With repeated contracting with borrowers, banks continuously gather information and update their evaluations of firm credit worthiness. Information is gathered through repeat lending or the provision of deposit and other information-intensive financial services. Berger and Udell (1998, p. 645) note that most small businesses have maintained a relationship with a bank for 9 years, and that a majority identify a commercial bank as their primary financial intermediary. Theory holds that small businesses that form relationships with a principal bank secure several advantages, including lower interest costs, greater credit availability, lower collateral demands, and protection against credit rationing in periods of firm distress. Yet, despite a general sentiment that firm-bank relationships are valuable, the empirical evidence remains inconclusive. 
This paper uses a unique contract-specific data set drawn from the records of a nineteenthcentury bank to analyze the value of firm-bank relationships. Such a data set has at least two advantages over widely used survey data. One potential advantage noted by Blackwell and Winters (1997) and Degryse and Van Cayseele (2000), who have recently turned to contract-specific data sets, is that focusing on a narrow set of lenders better controls for unobserved heterogeneity in bank lending standards and, therefore, borrower attributes. Second, most previous research has captured the nature of the firm-bank relationship by measuring the duration of the relationship, others include measures of relationship scope (the provision of complementary financial services) or relationship exclusivity (whether the current bank is a main bank). Using these measures, prior work has produced equivocal results. One explanation for the conflicting results, made evident with this data set, is that extended, extensive or exclusive relationships are not necessarily strong relationships. Some firms may rely on a single lender over a long period but borrow infrequently. Infrequent interaction, even if exclusive, is not the type of regular contracting envisioned in the theoretical literature (Boot 2000 provides a survey). Effective monitoring and screening likely requires repeat contracting at brief and regular intervals. Through regular contracting bankers realize cost economies because information is reused while it is fresh. This data set differentiates between longterm and frequent contracting and shows that frequency is, in some regards, as important as duration. Specifically, the results demonstrate three effects of repeat interaction on loan features: relationships reduce credit costs; frequent interaction reduces the use of collateral and personal guarantees; and long-term relationships positively affects credit availability in a financial crisis. The third issue -the influence of relationships on credit availability during a financial crisis -- has received the least attention. The so-called credit-channel hypothesis (Bernanke 1983; Bernanke and Blinder 1988) 
implies that monetary shocks will have disproportionate effects on small, bank-dependent borrowers. Ongena et al. (1999) investigate the results of bank distress on borrowing firms during the Norwegian bank crisis of 1988-1991. They find no support for the hypothesis that bank-dependent firms suffer more during a credit crunch than non-dependent firms. Their results, however, may be driven by the public's anticipation of a governmental bailout of the banking sector, which would have preserved banking relationships. This data set employs direct relationship measures and tests their effects on a bank's willingness to recontract during a financial crisis when there is neither implicit or explicit bailout guarantees. The results show that extended relationships are, indeed, valuable. This finding has potentially important policy implications for regulators.

\section{Theoretical Issues and Empirical Evidence}

The information approach to financial intermediation argues that intermediaries exist because they mitigate adverse selection and moral hazard problems that naturally arise in financing uncertain entrepreneurial projects. Intermediaries, particularly banks, capture economies of scale or exploit other comparative advantages in the production of information about borrowers (Freixas and Rochet 1997 provide a survey), which makes it more economic for small firms to borrow from banks than in arm's-length markets.

An important branch of the information approach is the emphasis placed on firm-bank relationships. Though quite different in approach, Diamond (1991) and Boot and Thakor (1994) develop models in which good borrowers reveal themselves, generate track records, and see their interest rates and collateral demands decline. Both approaches emphasize the benefits of developing extended firm-bank relationships and Boot (2000) outlines five potential benefits. First, lending 
relationships facilitate information reuse through time, which encourages information production and monitoring by lenders. Second, relationships facilitate flexible, implicit long-term contracting. Third, loan contracts typically include covenants to mitigate agency costs that become suboptimal as new information arrives. Depending on relative bargaining strengths, the development of longterm relationships facilitates low-cost renegotiation of covenants. Fourth, relationship lending often involves collateral or personal guarantees, and long-term contractual relationships encourage monitoring and the efficient use of costly collateral. Fifth, relationship lending accommodates the intertemporal smoothing of loan terms, which benefits young, informationally opaque firms.

The two principal costs of relationship lending are the soft budget constraint problem and the informational capture problem. Soft budget constraint problems arise when the borrowing firm becomes distressed. Distressed firms often approach lenders seeking additional finance to avoid or postpone default. Knowing that banks face incentives to support the firm in order to recoup the original loan, borrowers face perverse incentives to take inefficient risks or exert insufficient effort. A second cost of relationship lending is that banks gain informational advantages over borrowing firms and long-term dealings allow banks greater opportunities to exploit their advantage. Switching costs generate quasi-rents that current lenders appropriate. Further, banks in more concentrated markets are better positioned to capture quasi-rents by virtue of their market power.

Market power may benefit some borrowers, however. Sharpe's (1990) information-capture model shows that firms pay below-market loan rates early in the relationship (presumably when credit rationing for young firms without reputations is most severe) and then compensate the bank by paying above-market rates later in the relationship. If banks and borrowers can offer credible time-consistent commitments, it is optimal to offer the first-time borrower relatively low interest 
rates to avoid the adverse selection problem then recoup this early-period subsidization by charging supra-competitive rates later (Rajan 1998).

While the interest rate effects of efficient information production and potential problems of market power is one of the central themes of research on relationship banking, extant empirical evidence is conflicting. Using data compiled by the National Survey of Small Business Finance (NSSBF), Petersen and Rajan (1994) investigate credit costs and loan availability to more than 3,000 small businesses. They find no correlation between the duration of bank-borrower relationships and the cost of credit, but they find a strong positive relationship between credit availability and relationship duration. Berger and Udell (1995) argue that Petersen and Rajan's failure to find a negative correlation between credit costs and duration results from the inclusion of transaction loans in the analysis. By focusing their analysis on lines of credit (L/Cs), a type of lending more consistent with relationship banking, Berger and Udell find that credit costs and collateral use are declining in relationship duration. However, Cole (1998) uses a later NSSBF sample and concludes, like Petersen and Rajan, that relationship duration is a more important determinant of credit availability than credit cost.

Using contract-specific data from two bank holding companies, Blackwell and Winters (1997) find no statistical relationship between relationship duration and credit costs. Similarly, Elsas and Krahnen (1998), using contract-specific data from five German banks, fail to find any significant interest-cost advantage on lines of credit involving long-term bank relationships. Survey data on small firm L/Cs in Germany also fails to reveal any significant correlation between relationship duration and credit costs (Harhoff and Körting 1998).

Two studies find evidence broadly consistent with the information-capture hypothesis. 
Degryse and Van Cayseele (1998) gathered information on about 18,000 loans extended by a single Belgian bank to mostly small businesses. They find offsetting relationship effects. On one hand, the loan rate increases with the length of the relationship. On the other, loan rates decline with the scope of the relationship, defined as the purchase of other information-intensive services from the bank. The scope effect outweighs the duration effect. Angelini et al. (1998) find that at Italian banks other than credit cooperatives, loan rates tend to increase with the length of relationship. The same effect is seen for non-member borrowers at credit cooperatives. Among cooperative members, longterm relationships have no discernible effect on credit costs.

Thus empirical studies have found conflicting interest rate effects. If extended relationships generate benefits, how then might these benefits manifest themselves? One may be the availability of credit rather than its price. And, with the exception of Degryse and Van Cayseele (1998), all the above-cited empirical studies find a positive correlation between relationship duration and credit availability. A second benefit of long-term bank relationships may be a general decline in collateral usage.

Barro (1976), Benjamin (1978), Thakor and Udell (1991), Boot and Thakor (1994), and Rajan and Winton (1995) all contend that collateral reduces postcontractual opportunism. But collateral is a costly contractual device. It increases contracting costs because it necessitates additional contractual stipulations regarding the amount and type of collateral to be provided, the creditor's rights in taking possession in the event of default, and the borrower's control over the collateral during the term of the loan. Moreover, actual repossession and sale of the asset often imposes losses on the creditor as markets for some assets are thin and liquidations involve sizable opportunity costs. 
Although collateral may be an important element of many loan contracts, small business finance often involves personal guarantees rather than collateral. Collateral and guarantees are similar but not equivalent devices for dealing with postcontractual opportunism. Like collateral, guarantees allow financial institutions to offer credit on favorable terms to small businesses where informational opaqueness might otherwise result in credit rationing or outright denial. Collateral and guarantees differ, however, in that most loan agreements involving collateral include restrictions on the use to which borrowers may put the collateralized assets and prohibit their disposal without the lender's permission. Personal guarantees, on the other hand, represent a general claim against the total wealth of the guarantors and typically do not restrict the use of that wealth. Guarantees are more valuable than collateral when the personal assets of the guarantors may be more easily valued or sold than highly firm-specific assets, or if the principal asset of the borrowing firm is the human capital of its owners. Nevertheless, guarantees generally represent a weaker pledge than specific collateral because most loan covenants do not restrict guarantors from selling or redeploying their assets, or from pledging them to another lender. Guarantees are useful, however, to the extent that they align the guarantors' and the lender's interests.

Empirical evidence usually finds collateral usage associated with risky borrowers and risky loans (Berger and Udell 1990). This is contrary to much existing theory, which holds that good borrowers signal their better prospects through their willingness to pledge collateral. Evidence on the effects of relationships on loan collateral is mixed. Harhoff and Körting (1998) find the longer relationships involve less collateral, but Degryse and Van Cayseele (2000) find that main banks tend to demand more collateral. They argue that informational capture has both interest rate and collateral consequences. As the relationship progresses, banks become better informed about a firm's 
collateral and shift more default risk onto the borrower. On the other hand, better information about collateral may reduce the cost of including collateral covenants in the loan contract, which makes collateral usage more efficient. No study of the consequences of relationships on personal guarantee usage exists. The introduction of personal guarantees into the study of bank relationships represents one of the principal contributions of this research.

Existing empirical studies offer broad support for the hypothesis that long-term relationships positively affect credit availability (see Ongena and Smith 2000 for a review). What these studies have failed to do is link relationship effects with credit availability during a periods of sharp financial stress. Economists have long posited that a transmission mechanism linking financial sector performance to real sector outcomes, a mechanism that becomes manifest in financial crises (Fisher 1933). Bernanke (1983) and Bernanke and Blinder (1988) argue that panic-induced disintermediation affects real activity by restricting the flow of financial services to borrowers without access to nonbank credit. One empirical prediction arising from this theory is that newer borrowers face tighter credit conditions than those with longer track records when both types of firms face liquidity constraints (Gertler 1988). With information asymmetries, lenders tend to know more about long-term customers. This plays a crucial role in reinforcing the financial consequences of a panic. Young and small firms rely on bank-intermediated finance because they have not developed publicly observable track records, which denies them access to arm's-length debt markets. With banks experiencing disintermediation and firms experiencing deteriorating balance sheets, lenders are more likely to renegotiate existing loans or extend new ones to long-term customers. Evidence on Japanese main banks (Hoshi, Kashyap and Scharfstein 1990) provides support for this contention. This paper investigates the behavior of one bank during a severe financial crisis and shows that it 
was, in fact, more willing to recontract with longer-term borrowers.

\section{Data Source}

The data are drawn from the records of the Black River Bank of Watertown, New York. Loveland Paddock founded the bank in autumn 1844 under New York's free banking act of 1838. Paddock had extensive prior banking experience. He had been a director in the Jefferson County Bank as early as 1828; a shareholder and director of the Sacket's Harbor Bank in the late 1830s and early 1840s; and a founding director of the Watertown Bank and Loan (1839-1842). Between 1842 and 1844 he divested his holdings in these other banks, renounced his directorships, sold his dry goods business and opened his own bank. Paddock controlled 90 percent of the stock in the Black River Bank, the remaining 10 percent was divided between his two eldest sons, one of whom was the bank's vice president, the other its cashier (Emerson 1898, p. 336).

Emerging from the depression of the early 1840s, the decade after 1845 was a period of economic expansion. In current dollars, U.S. GNP increased at an average annual rate of 5.92 percent between 1846 and 1855; in constant dollars, GNP increased at an average annual 3.70 percent (Berry 1978). Expansion of the regional economy of northern New York mirrored national trends. Although agriculture remained the region's principal employer, Watertown emerged as a transportation hub as well as a manufacturing and commercial center. Encouraged by the opening of two railroads (one connected Watertown to Lake Ontario to the north, the other to Lake Champlain to the east) and a canal (a feeder line for the Erie Canal), wheat production increased by 7.3 percent between 1850 and 1860 . Manufacturing also grew apace. During the 1850 s, the nominal value of capital invested in manufacturing increased at an average annual rate of 2.6 percent. The 
nominal value of manufacturing output increased at an average annual rate of 3.5 percent (U.S. Census Office 1854, 1865).

Watertown also emerged as a regional financial center and the Black River Bank became a principal player. In February 1845, the Black River Bank had just \$28,000 in outstanding loans and about $\$ 95,000$ in total assets. This made the bank about half the size of the Bank of Watertown and about one-tenth the size of the Jefferson County Bank. Within a decade the bank established itself as one of the region's leading banks, and in December 1855 the Black River Bank’s had \$482,000 in outstanding loans, compared to $\$ 563,000$ at the Jefferson County Bank and $\$ 380,000$ at the Watertown Bank and Loan (New York Assembly 1857). The Black River Bank was, by every outward appearance, a typical commercial bank in 1850s New York.

Because the bank's market share and lending volume stabilized by 1855 and because the economy was near the end of a decade-long expansion, contract-specific information was collected on every loan made in 1855 (a year that should approximate equilibrium bank practice). Of the 2,674 loans made in 1855, there were 978 distinct borrowers, so that the average customer borrowed 2.7 times. The bank, like most banks of the antebellum period, specialized in short-term lending, with an average loan maturity of just 68.2 days. Just 3.5 percent of its loans were renewed (renegotiated and extended) at maturity. The mean dollar value was $\$ 776$ (about $\$ 15,250$ in constant 2000 dollars) and the mean interest rate was 7.05 percent.

The bank's hand-written loan records included the name of the borrowing firm or individual, the date of the loan, the date the loan matured, the loan amount, whether the loan was a renewal, and the total interest charge. Annualized interest rates on loans were calculated as $\mathrm{i}=$ (interest charge/loan amount $) *(365 /$ days to maturity). In the mid-nineteenth century, banks extended credit 
on two types of instruments: promissory notes and bills of exchange. A promissory note was a simple IOU stating the borrowers' names, the date of the loan, the date of maturity, the amount of the loan and where the note was payable (typically the borrower's place of business or the lending bank). Promissory notes were not collateralized, but commercial law held that the borrower's real and personal estate guaranteed the note. If a borrower's personal wealth was an insufficient pledge to compensate the bank for its expected default costs, the bank asked borrowers to obtain the signatures of one or more cosigners or third-party guarantors, who added their personal guarantee to the borrower's note. If the borrower defaulted, the bank notified all cosigners and instituted proceedings to attach their property. Although promissory notes were not collateralized, they were secured and the more so the more third-party guarantees. The bank's records include the names of all endorsers for each loan, making it possible to determine the number of guarantors demanded of each borrower.

The second principal contractual form of nineteenth century bank lending was the bill of exchange. Bills of exchange differed from promissory notes in two regards. First, they were payable at distant locations. A typical bill transaction in 1850s Watertown involved a local wheat merchant discounting a bill at a local bank to finance a shipment of wheat to New York City. Because the funds were realized in New York City, the bill was payable there, typically at a bank where the shipper maintained an account. Thus the local lender faced the costs of drawing on a correspondent bank to repatriate its funds. To compensate the banker for these additional costs, bills paid an "exchange" fee in addition to the interest charge. Loan records do not explicitly record the fee, but they averaged about one-quarter of one percent in the mid-1850s. The second way in which bills differed from notes was that legitimate bills carried an attached bill of lading, which detailed the 
specific goods in transit. These goods represented implicit collateral because, in the event of default, the goods were liable to seizure and sale. To protect themselves, banks typically loaned about onethird to one-half the current market value of the goods in transit on bills of exchange, but if this collateral was unsatisfactory banks asked borrowers to obtain endorsements just as with promissory notes. The loan records of the bank differentiate between bills of exchange and promissory notes, in that bills were listed as payable in New York City, Albany or Boston, and listed the names of all endorsers. The bank protected itself from losses on bill loans through a combination of collateral and personal guarantees.

Two relationship measures were constructed from this data. First, the list of all borrowers in 1855 was matched to the bank's extant loan records (which begin in October 1845) to determine the month and year that each firm first borrowed. The interval between the first loan and any loan(s) in 1855 was recorded to the nearest month. Second, the matching also revealed the number of times the firm had borrowed in the previous decade. This measure represents an advance over previous research because most studies use measures of relationship duration. In constructing a second measure based on relationship intensity, this study captures the effects of more intensive relationships as well as long-lasting ones. Shorter, but more intense, relationships may provide bankers with timely information. It is not possible to control for relationship scope because the deposit records of the bank are lost.

Table 1 reports summary statistics for the relevant variables used in the empirical analysis. Bills of exchange are identified by the city where payable (New York, Albany or Boston) and represent the collateral associated with their use. About 30 percent of the bank's loans were bills of exchange. The GUARANTEE variable is the number of third-party guarantors, with larger 
numbers representing greater security for the lender. The QUARTER dummies show that loans were evenly spaced over the year. Most empirical studies of relationship effects regress various determinants of loan rates on a premium of the bank loan rate over a prime rate of similar maturity. In the antebellum era, the analog of the prime rate was the prevailing rate on good bills of exchange (or commercial paper) in New York City. The loan premium is calculated as the difference between the loan rate and the market rate on good bills in the same week the loan was made. Data on the prime rate in New York City was gathered from the New York Tribune.

Despite the presence of a reasonably active commercial paper market in New York City and other port cities, small business finance in early America was bank-based finance. Only large, wellknown mercantile houses regularly placed commercial paper in the open market. Most borrowers relied on banks or private capitalists (Greef 1938). Bond and equity markets were restricted to the few existing corporations, mostly banks, insurance companies, canals, and railroads. Thus, early American financial markets provide a unique opportunity to investigate the importance of relationships in a bank-based environment.

\section{Empirical Results}

The empirical analysis tests whether bank relationships influence credit costs, the use of guarantees, and credit availability during a financial panic.

\subsection{Relationships and Loan Rates}

In this section we relate an ex ante measure of loan risk to several control variables in addition to the two relationship measures. The dependent variable is the loan risk PREMIUM, or the difference between the contract-specific loan rate and the market rate on high-grade commercial 
paper of similar maturity (60-90 days). The risk premium should incorporate ex ante evaluations of loan risk as well as any relevant premium for monitoring costs associated with secured lending, whether the security was collateral or personal guarantees.

The independent variables of principal concern are LNTIMES and LNMONTHS. LNTIMES is defined as the natural log of one plus the number of times a firm had previously borrowed from the bank. It is included to capture intensive relationships based on regular contracting. In such relationships, the bank should capture scale economies by reusing information produced about the borrower. LNMONTHS is defined as the natural $\log$ of one plus the number of months over which a firm had maintained a relationship with the bank regardless of the number of times it had borrowed. It is included to capture long-lasting relationships that may or may not have been based on regular contracting. Several instances were found where firms borrowed from the bank over a decade or more, but some loans were separated by up to four years. Such long-term relationships may foster information reuse, but borrowings separated by extended periods may not lead to scale economies in information production and reuse if four-year-old information is stale.

Control variables include a number of variables included to capture the effects of collateral usage. Because bills of exchange carried implicit collateral, the dummy variables NEWYORK, ALBANY, and BOSTON represent the city where bills were made payable and are included separately to capture any unobserved differences in goods shipped (the underlying collateral) to different cities. GUARANTEE represents increased security for lenders in that larger values are associated with more cosigners and captures differences in borrower risk. Its inclusion reveals whether riskier borrowers or borrowers with riskier projects offered greater security. LNSIZE accounts for any exploitable scale economies in lending; that is, whether lower rates were paid on 
larger loans. Loan size may also be correlated with unobserved credit risks if the bank allowed safer borrowers larger lending limits. LNMATURITY is included to capture nonrisk term premiums priced into longer duration loans. The RENEW dummy variable equals one if the loan was renegotiated and extended. Renewed loans may have been riskier in that the project had not generated sufficient funds to repay them in the stipulated time, or they may have been safer in that a firm's project was successful and the loan extended to pursue it farther. Finally quarterly dummies were included to capture seasonal differences in loan demand. The historiography of early American banking holds that loan demand increased sharply in the fourth and first quarters (particularly October through January) as farm produce was moved to market. Aggregate data suggests that this pressure tended to induce greater price than quantity responses, a feature confirmed by response of the Black River Bank, which spaced its loans evenly throughout the year.

A potential criticism of the empirical analysis is the lack of firm-level balance sheet information. But accounting standards in the 1850s were loose to nonexistent and it is unlikely that small firms prepared regular balance sheets and it is even less likely that any that did made them available to bankers. Even double-entry bookkeeping, while not unknown, was uncommon. Similarly, no industry effects are included. Lending rates, as well as collateral and guarantee usage, reflect industry differences, but such effects were probably small. Of the borrowers who were identified, most were merchants and artisans borrowing working capital to financed goods in process or transit. Any substantial industrial differences are likely captured in differences in loan size, maturity, and place of payment.

Table 2 presents the results for four regressions of the loan risk premia on the control and relationship variables. Columns (1) and (3) report OLS parameter estimates. The estimates show 
that long-term relationships did, in fact, reduce credit costs. The coefficient on LNTIMES in column (1) is significantly negative, which implies that the loan rate is decreasing in the intensity of the relationship. The LNMONTHS coefficient in column (3) is also significantly negative, implying that the loan rate is decreasing in relationship duration. Theory holds that relationships are valuable because they afford information reuse. The results imply that some of the cost savings attributable to information reuse were passed along to borrowers as lower rates. Some of the effect, however, may be attributable to unobserved differences in firm age. Several previous studies find that longerlived firms tend to pay lower rates and the LNMONTHS variable may be capturing an age, as well as a relationship effect. The LNTIMES variable may or may not be capturing an unobserved age effect because some firms borrowed extensively in relatively short periods. And the differences could be striking. One merchant borrowed at least once each year between 1845 and 1855, but never more than 5 times; another first appeared in 1852, borrowing 25 times in that year and 75 times in the next.

The control variables generally enter with the expected signs. Loans payable outside the region paid smaller premia, reflecting the implicit collateral carried by bills of exchange. While loans with more GUARANTEES paid higher rates, implying riskier loans or riskier borrowers, the estimates are not significantly different from zero. The surprising result is the large and positive coefficients on the Q2 and Q3 variables. Loan demand slackened once farm produce was moved to market, which suggests that the higher rates paid on spring and summer loans reflect risk premia. This accords with the nineteenth-century bankers adage, which held that "June loans and June-bugs are no good" because summer loans often financed more speculative activities. It also reflects, in part, a seasonal decline in commercial paper rates as demand declined in spring and summer. Bank 
rates exhibited less pronounced seasonal movements.

Due to the presence of several outliers, the equations were estimated using robust regression methods, which underweight large outliers. Even after controlling for the presence of outliers, the relationship variables continue to enter negatively and significantly. The results, therefore, are unlikely to be driven by a handful of borrowers who borrowed extensively. Coefficients on the control variables are generally smaller and somewhat less significant using robust regression, but tend to mimic the OLS estimates.

Overall, the results of this section are consistent with the information-advantage hypothesis of bank lending in that loan rates decline the longer or more intense the firm-bank relationship, and parallel the results reported in Berger and Udell (1995). The results do, however, stand in sharp contrast to those reported in Petersen and Rajan (1994), Blackwell and Winters (1997), Harhoff and Korting (1998) and Elsas and Krahnen (1998) who find no significant effect of relationship duration on credit costs, and studies by Degryse and Van Cayseele (1998) and Angelini et al. (1998) who find interest rates increasing in duration. It is difficult to square these other findings with the results reported above except to point out that the duration effect (LNMONTHS) is marginally smaller than the intensity effect (LNTIMES), so that duration measures in previous studies may not be capturing the full effect of many firm-bank relationships. Relationships are valuable because they foster information reuse, and information is best reused while fresh. A firm's financial condition can change rapidly, implying that track records, in and of themselves, do not always convey a great deal of information.

\subsection{Relationships and Personal Guarantees}


This section empirically investigates the connection between firm-bank relationships and the use of personal guarantees. Because guarantee data is count data (e.g., $0,1,2,3, \ldots$ separate guarantors), the most appropriate empirical technique is Poisson regression. Poisson regression is specifically designed for use with count data in which observed outcomes assume nonnegative integer values. It is commonly used to study such things as the number of telephone connections to wrong numbers under varying conditions, disease incidence per year, or automobile accidents per day. The procedure has been used by economists in studies of entry (Bodenhorn 1990) and patents (Hausman, et al. 1984). A study of guarantee usage represents an important extension of Avery, et al. (1998), who find that a majority of small firms carry personal guarantees but lacked information on firm-bank relationships. Similarly, Berger and Udell's (1998) survey offers few insights into guarantee usage owing to the lack of prior studies. This section adds to the literature by discussing the impact of relationships on guarantee usage.

For all loans in the sample, we know the number of outside guarantors to each loan, but know nothing about their occupation, wealth, or connection to the borrowing firm. One loan was excluded because the loan records listed "collateral" in the guarantor column without identifying what that collateral was. Table 3 reports the results of two Poisson regressions. As in the previous section, two distinct relationship variables are included in the regressions, LNTIMES and LNMONTHS. Controls for place of payment, which captures any offsetting effects collateral may have on guarantee usage, loan size, loan maturity, seasonal effects, and renegotiated or renewed loans are also included. Just as above, we have no firm-specific information. But it remains likely that the loan size, loan maturity and place of payment variables capture unobserved industry heterogeneity.

Parameter estimates in column (1) show that firms that borrowed more frequently provided 
significantly fewer third-party personal guarantees. Column (2) reports incidence rate ratios (IRRs), which facilitate the economic interpretation of the results. The 0.96 IRR for the LNTIMES variable implies that a firm with a one unit increase in the $(\log )$ number of prior loans offered 0.96 times as many (or 4 percent fewer) guarantors as a firm with a mean $(\log )$ number of prior borrowings. The results in column (3), using LNMONTHS as the relationship measure, are similar. Relationships of longer duration are associated with significantly lower use of guarantees. The 0.98 IRR implies that a unit increase in the $(\log )$ number of months of firm-bank interactions led to 0.98 times as many (or 2 percent fewer) guarantors as a firm with a mean (log) number of borrowings. As in the credit cost regressions, relationship duration had a smaller impact than intensity on guarantee usage.

Theory holds that collateral and guarantees mitigate postcontractual opportunism and other information problems. Where collateral resolves adverse selection problems when the borrower has more information about project quality than the lender, third-party guarantees resolve problems when outsiders other than the banker are in a better position to judge the general risk attitudes of the borrower or the specific risk attributes of the contemplated project. Collateral too is also viewed as a means of attenuating moral hazard and effort problems. Third-party guarantees may be superior to collateral in certain circumstances. Unlike collateral, which provides the lender with recourse against specific assets, third-party guarantees represent a generalized claim against the totality of the guarantors' estates. Such generalized claims are effective when the guarantor's disutility of losing assets is great. Generalized claims are called for when the firm's principal asset is the entrepreneur's human capital. Moreover, collateral requires lender monitoring to ensure that the borrower is not dissipating the firm's assets. Third-party guarantees elicit outside monitoring and reduce interim lending costs and risks. Thus, guarantees secured by modest amounts of personal wealth may benefit 
the lender even if the guarantors' personal assets represent only a small fraction of the value of the loan (Berger and Udell 1998, p. 639).

The regression results, in fact, suggest that the Black River Bank viewed guarantees as distinct from yet complementary to specific collateral. The bank demanded significantly more guarantors on bills of exchange that already carried a legally enforceable collateral covenant. Incidence rate ratios reported in column (2) of Table 3 show that the bank demanded 1.19 times the number of guarantors for loans payable in New York City, after controlling for relationship intensity. Similarly, the bank demanded 1.14 times as many guarantors for loans payable in Albany and 1.13 times the number of guarantors for loans payable in Boston. Equivalent results obtain in column (4) when we use the relationship duration variable. The reason for this seemingly anomalous outcome may been caused by the relatively slow communications between New York City and northern New York state (about 2 to 3 days in the mid-1850s). Possibilities for fraud or asset dissipation surely represented a concern for a banker unable to monitor effectively from a distance. By requiring additional guarantors, the bank mitigated its risk exposure.

This discussion of the simultaneous use of collateral and third-party guarantees adds a new dimension to the existing debate on the consequences of relationship banking. Previous studies provide mixed results. Harhoff and Körting (1998) find that collateral requirements decline with relationship duration. Degryse and Van Cayseele (2000), on the other hand, find that main banks demand more collateral. They argue that an informational lock-in operates as lenders become better informed about a borrower's collateral. While this reduces the cost of collateral use, it also shifts default risk from lenders to borrowers. Avery et al. (1998) find that guarantee use decline with firm age, but that fails to illuminate any possible relationship effects. An important line of future research 
is to deepen our understanding of the consequences of guarantees, especially third-party guarantees, on bank lending behavior.

\subsection{Relationships and Financial Crises}

This section tests whether firms benefitted from extensive or extended bank relationships during a financial crisis. The records of the Black River Bank provide us with data to conduct a test of the hypothesis that a bank was more willing to renegotiate with long-time customers or relative newcomers. A sharp financial panic erupted in autumn 1857. Triggered by the declining railroad profits and the collapse of the Ohio Life and Trust Company, the panic radiated out from New York City (Calomiris and Schweikart 1991). Scores of banks failed, nearly all others declared a payments holiday, refusing to redeem their banknotes or deposits in specie. A liquidity scramble developed and business failures increased dramatically as banks refused to renegotiate or renew existing loans or extend new ones. Small businesses were particularly hard hit. Those fortunate to obtain arm'slength credit in commercial paper markets paid exorbitant rates. Commercial paper rates in New York city, which averaged 8.5 percent per annum in the first eight months of 1857, peaked at 36 percent on 14 October (New York Tribune 1857). The panic subsided quickly. By January 1858, commercial paper rates fell to 7 percent; by April they fell to just 4 percent.

Although the panic drove up open market lending rates only briefly, the records of the Black River Bank indicate that its consequences lingered in the hinterland. In late 1857 and through 1858, the bank's lending practices changed markedly. Compared to the previous three years, the number of loans fell by nearly four-fifths, the number of different borrowers fell by nearly three-quarters, the mean loan amount fell by one-fourth, and the mean loan rate declined by 17 basis points. One of the 
most notable changes, however, was the marked increase in the number of renegotiated loans. In 1855 the bank renewed just 3.5 percent of its outstanding loans; in 1856 just 5.1 percent. In the last four months of 1857 , the bank renewed 10.2 percent of its loans, and 16.9 percent in 1858 . Thus, the data provide a remarkable natural experiment on relationships and loan renegotiation during a financial panic.

To test the hypothesis, information was gathered on 519 loans maturing between 26 August 1857, when commercial paper rates jumped sharply, reflecting initial financial market pressure, and 29 December 1857, when commercial paper rates returned to pre-panic levels. In addition to the same types of data gathered for the 1855 sample (e.g., loan maturity, loan size, place of payment, and guarantors), any loan renegotiated during the panic was linked to the original loan. The sample of 519 loans, then, consists of 40 renegotiated loans definitively linked to the original loan and 479 nonrenewals. Twelve renegotiated loans could not be definitively linked and were dropped.

The empirical analysis runs headlong into the problem of distinguishing between supply and demand effects because no information exists on rejected renewal applications. While some firms with loans maturing during the panic may not have applied for a renewal, contemporary observers describe a classic liquidity scramble in which most borrowers sought to extend or alter existing loan agreements even while most banks refused to renegotiate (Gibbons 1859). The following analysis assumes that borrowers not receiving renewals were effectively credit rationed. Nevertheless, the small proportion of observed successes and the possibility that some renegotiated loans were recorded as new rather than renewals biases the empirical analysis against finding significant relationship effects.

Table 4 reports the results of two probit specifications. Loans renegotiated during the credit 
crunch taking a value of one, all others were coded with zeroes. As expected with a small proportion of successes and the likelihood that the bank's decision-making procedures changed markedly during a financial crisis, there are few significant parameter coefficients. The regressions provide mixed relationship results. LNTIMES takes the expected positive sign but it is small and insignificant. Notably, however, the LNMONTHS variable enters positively and significantly. This represents a reversal of findings in the previous sections where the intensity variable (LNTIMES) entered with greater explanatory power than the duration variable (LNMONTHS). This finding may reflect the significant benefit accruing to firms that develop lasting bank relationships; namely, that they avoid the worse effects of credit rationing during a financial crisis. The duration variable is likely capturing the combined effects of information production over the course of a relationship and firm longevity or survival. Long-lived firms are more likely to have proved themselves capable of weathering short-term macroeconomic fluctuations.

The maturity variable (LNTERM) is the other important variable that enters both specifications significantly, which lends support to the hypothesis that banks screen with private information. If monitoring is most effective if conducted at short and regular intervals, in that it offers borrowers fewer opportunities to engage in dissipative behavior, the bank's willingness to renegotiate with borrowers with longer loan maturities suggests that the bank already viewed these as lower-risk borrowers.

These results are consistent with theoretical predictions, as well as the empirical evidence of Kashyap, Stein and Wilcox (1993), wherein debt-deflation problems in the banking sector manifest themselves in real sector slowdowns. As borrower balance sheets deteriorate during a credit crunch, banks further restrict lending, which places those firms most reliant on bank credit 
directly in harm's way. A long-term relationship with a bank mutes the negative consequences of short-term liquidity constraints. Because banks have superior information on long-time customers they renegotiate more readily with these customers when their projects or ultimately profitable but are, like banks, liquidity constrained. Long-term relationships thus rationalize credit allocation during financial crises and credit crunches.

\section{Conclusions}

This paper has provided empirical tests of three hypotheses concerning bank behavior under conditions of asymmetric information. Each test emphasizes the primacy of relationships between banks and borrowers. The evidence indicates that small firms excluded from arm's-length markets find it advantageous to form extensive and durable relationships with banks. Repeat borrowing over long periods leads to lower interest costs, lower guarantee usage, and a greater likelihood of maintaining a bank relationship during financial panics and other macroeconomic downturns. In each case, these effects are statistically and economically significant.

The results are consistent with the theoretical finance literature, which argues that reputation effects are important in both arm's-length and bank-based loan transactions. Lenders accumulate information over the life of the borrowing relationship and refine loan terms as conditions change and as new information arrives. Such relationship effects are important because small firms are heavily reliant on bank financing and because small firms are more informationally opaque than large firms with publicly observable reputations.

Although the findings reported here are generally consistent with the hypothesis that banking relationships are valuable to both the banker and the borrower, this research, like most other 
empirical research, is silent about the precise nature of these benefits and from whence they spring. While the evidence suggests that banks produce and use proprietary information about their customers over time, little is known about how the information is produced, exactly what information is produced, and how that information is used once it is produced. Future research, particularly micro-level research, should address these issues.

\section{$\underline{\text { References }}$}

Angelini, P., E. Di Salvo, and G. Ferri. "Availability and Cost of Credit for Small Business: Customer Relationships and Credit Cooperatives.” Journal of Banking and Finance 22 (1998), 925-954.

Avery, Robert B., Raphael W. Bostic, and Katherine A. Samolyk. "The Role of Personal Wealth in Small Business Finance.” Journal of Banking and Finance 22 (August 1998), 1019-1061.

Barro, Robert J. "The Loan Market, Collateral, and Rates of Interest." Journal of Money, Credit, and Banking 8 (1976), 439-56.

Benjamin, Daniel K. “The Use of Collateral to Enforce Debt Contracts.” Economic Inquiry 16 (July 1978), 333-59.

Berger, Allen N. and Gregory F. Udell. "Collateral, Loan Quality, and Bank Risk." Journal of Monetary Economics 25 (January 1990), 21-42.

Berger, Allen N.and Gregory F. Udell. "Relationship Lending and Lines of Credit in Small Firm Finance.” Journal of Business 68 (July 1995), 351-81.

Berger, Allen N. and Gregory F. Udell. "The Economics of Small Business Finance: The Roles of 
Private Equity and Debt Markets in the Financial Growth Cycle." Journal of Banking and Finance 22 (1998), 613-673.

Bernanke, Ben S. "Nonmonetary Effects of the Financial Crisis in the Propagation of the Great Depression.” American Economic Review 73 (June 1983), 257-76.

Bernanke, Ben S. and Alan S. Blinder. "Credit, Money, and Aggregate Demand." American Economic Review 78 (May 1988), 435-439.

Berry, Thomas Senior. Revised Annual Estimates of American Gross National Product. Richmond: Bostwick Press, 1978.

Blackwell, David W. and Drew B. Winters. "Banking Relationships and the Effect of Monitoring on Loan Pricing.” Journal of Financial Research 20 (Summer 1997), 275-289.

Bodenhorn, Howard. "The Business Cycle and Entry into Early American Banking." Review of Economic and Statistics 75 (August 1993), 531-35.

Boot, Arnould W.A. "Relationship Banking: What Do We Know?" Journal of Financial Intermediation 9 (January 2000), 7-25.

Boot, Arnould W.A. and Anjan V. Thakor. "Moral Hazard and Secured Lending in an Infinitely Repeated Credit Market Game.” International Economic Review 35 (November 1994), 899920.

Boot, Arnould W. A., Anjan V. Thakor, and Gregory F. Udell. "Secured Lending and Default Risk: Equilibrium Analysis, Policy Implications and Empirical Results.” Economic Journal 101 (May 1991), 458-72.

Calomiris, Charles W. and Larry Schweikart. "The Panic of 1857: Origins, Transmission, and Containment.” Journal of Economic History 51 (December 1991), 807-34. 
Cole, Rebel A. "The Importance of Relationships to the Availability of Credit." Journal of Banking and Finance 22 (1998), 959-977.

Degryse, Hans and Patrick Van Cayseele. "Relationship Lending within a Bank-Based System: Evidence from European Small Business Data." Journal of Financial Intermediation 9 (January 2000), 90-109.

Diamond, Douglas. "Financial Intermediation and Delegated Monitoring." Review of Economic Studies 51 (1984), 393-414.

Diamond, Douglas. "Monitoring and Reputation: The Choice between Bank Loans and Directly Placed Debt.” Journal of Political Economy 99 (1991), 688-721.

Elsas, Ralf and Jan Pieter Krahnen. "Is Relationship Lending Special? Evidence from Credit-File Data in Germany.” Journal of Banking and Finance 22 (1998), 1283-1316.

Emerson, E.C. Our Country and Its People: A Descriptive Work on Jefferson County, New York. Boston: Boston History Company, 1898.

Fisher, Irving. "The Debt-Deflation Theory of Great Depressions.” Econometrica 1 (October 1933), $337-57$.

Freixas, Xavier and Jean-Charles Rochet. Microeconomics of Banking. Cambridge, MA: MIT Press, 1997.

Gertler, Mark. "Financial Structure and Aggregate Economic Activity: An Overview." Journal of Money, Credit, and Banking 20 (August 1988), 559-88.

Greef, Albert. The Commercial Paper House in the United States. Cambridge, MA.: Harvard University Press, 1938.

Harhoff, Dietmar and Timm Korting. "Lending Relationships in Germany -- Empirical Evidence 
from Survey Data." Journal of Banking and Finance 22 (1998), 1317-1353.

Hausman, J., B. Hall and Zvi Griliches. "Econometric Models for Count Data with an Application to the Patents-R\&D Relationship.” Econometrica 52 (1984), 909-38.

Hoshi, Takeo, Anil Kashyap, and David Scharfstein. "The Role of Banks in Reducing the Costs of Financial Distress in Japan.” Journal of Financial Economics 27 (1990), 67-88.

Jefferson County Historical Society. Records of the Black River Bank: Discount Books \#2 and \#3.

Kashyap, Anil K., Jeremy C. Stein, and David W. Wilcox. "Monetary Policy and Credit Conditions: Evidence from the Composition of External Finance.” American Economic Review 83 (March 1993), 78-98.

New York Assembly. Annual Report of the Superintendent of the Banking Department. Assembly Document No. 5. Albany, 1857.

New York Tribune, various issues, 1855-1858.

Ongena, Steven, and David C. Smith. "Bank Relationships: A Review." In Performance of Financial Institutions: Efficiency, Innovation, Regulation, edited by Patrick T. Harker and Stavros A. Zenios, pp. 221-258. Cambridge: Cambridge University Press, 2000.

Ongena, Steven, David C. Smith, and Dag Michalsen. "Distressed Relationships: Lessons from the Norwegian Banking Crisis (1988-1991).” Mimeo, University of Florida, (December 1999).

Petersen, Mitchell A. and Raghuram G. Rajan. "The Benefits of Lending Relationships: Evidence from Small Business Data.” Journal of Finance 49 (March 1994), 3-37.

Rajan, Raghuram G. "The Past and Future of Commercial Banking Viewed through an Incomplete Contract Lens." Journal of Money, Credit, and Banking 30 (August 1998), 524-50.

Rajan, Raghuram and Andrew Winton. "Covenants and Collateral as Incentives to Monitor." 
Journal of Finance 50 (September 1995), 1113-46.

Ramakrishan, Ram and Anjan V. Thakor. "Information Reliability and a Theory of Financial Intermediation.” Review of Economic Studies 51 (1984), 415-432.

Sharpe, Steven. “Asymmetric Information, Bank Lending and Implicit Contracts: A Stylized Model of Customer Relationships.” Journal of Finance 45 (1990), 1069-1087.

U.S. Census Office. Statistical View of the United States. Washington, D.C.: Beverly Tucker, 1854.

U.S. Census Office. Manufactures of the United States. Washington, D.C.: GPO, 1865. 
Table 1. Variable Definitions and Summary Statistics for Loans Extended in 1855

\begin{tabular}{llll}
\hline Variable & Definition & Mean & Std Dev \\
\hline RATE & Loan Rate & 7.152 & 1.201 \\
PRIME & Rate on A-1 commercial paper & 6.773 & 1.557 \\
PREM & RATE-PRIME & 0.379 & 1.915 \\
NYC & Loan payable in New York City $(0,1)$ & 0.176 & 0.381 \\
ALBANY & Loan payable in Albany (0,1) & 0.093 & 0.290 \\
BOSTON & Loan payable in Boston $(0,1)$ & 0.029 & 0.168 \\
GUARANTEE & Number of endorsers & 1.338 & 0.701 \\
TERM & Loan maturity in days & 68.13 & 25.78 \\
SIZE & Loan amount in dollars & 744.31 & 1312.60 \\
RENEW & Renewed/renegotiated loan (0,1) & 0.036 & 0.186 \\
Q1 & Loan made in first quarter & 0.254 & 0.436 \\
Q2 & Loan made in second quarter & 0.255 & 0.436 \\
Q3 & Loan made in third quarter & 0.259 & 0.438 \\
MONTHS & Length of bank relationship in months & 49.58 & 43.37 \\
TIMES & Number of previous borrowings & 34.08 & 59.55 \\
\end{tabular}

Notes: Dichotomous variables indicated with $(0,1)$. All other variables are continuous and reported in levels. Loans payable in New York City, Albany, and Boston are bills of exchange. The prime rate is the rate on first-class or A-1 bills of exchange (commercial paper), and is the rate quoted at the end of the week in which the bank loan was made. Q1 ends April 30; Q2 ends July 31; Q3 ends October 31. This unusual definition accords with the quarter definitions used by the New York state bank commissioners in the 1850s. Their choice reflected the post-harvest peak loan demand in October and spring trough usually occurring in April. Sources: Loans data, Black River Bank Records, Discount Book \#2; prime rate, New York Tribune, 1855. 
Table 2. Regressions of Loan Risk Premia (in basis points) on Relationship and Control Variables

\begin{tabular}{|c|c|c|c|c|}
\hline Variable & $\begin{array}{l}\text { (1) } \\
\text { OLS }\end{array}$ & $\begin{array}{l}(2) \\
\text { Robust } \\
\text { Regression }\end{array}$ & $\begin{array}{l}\text { (3) } \\
\text { OLS }\end{array}$ & $\begin{array}{l}\text { (4) } \\
\text { Robust } \\
\text { Regression }\end{array}$ \\
\hline Intercept & $\begin{array}{c}139.36 * * * \\
(4.62)\end{array}$ & $\begin{array}{c}-53.65^{* * *} \\
(2.96)\end{array}$ & $\begin{array}{l}144.15^{* * *} \\
(4.78)\end{array}$ & $\begin{array}{l}-50.64 * * * \\
(2.79)\end{array}$ \\
\hline NYC & $\begin{array}{c}-19.32 * * \\
(2.20)\end{array}$ & $\begin{array}{c}2.97 \\
(0.56)\end{array}$ & $\begin{array}{c}-21.58^{* *} \\
(2.49)\end{array}$ & $\begin{array}{c}1.36 \\
(0.26)\end{array}$ \\
\hline ALBANY & $\begin{array}{r}-1.69 \\
(0.14)\end{array}$ & $\begin{array}{c}10.22 \\
(1.44)\end{array}$ & $\begin{array}{c}-3.60 \\
(0.31)\end{array}$ & $\begin{array}{c}8.88 \\
(1.25)\end{array}$ \\
\hline BOSTON & $\begin{array}{c}-52.04 * * * \\
(2.90)\end{array}$ & $\begin{array}{c}-11.16 \\
(1.04)\end{array}$ & $\begin{array}{c}-54.57 * * * \\
(3.07)\end{array}$ & $\begin{array}{r}-12.50 \\
(1.17)\end{array}$ \\
\hline GUARANTEE & $\begin{array}{c}5.57 \\
(1.35)\end{array}$ & $\begin{array}{c}2.49 \\
(1.00)\end{array}$ & $\begin{array}{c}5.95 \\
(1.45)\end{array}$ & $\begin{array}{r}2.70 \\
(1.09)\end{array}$ \\
\hline RENEW & $\begin{array}{r}-23.42 \\
(1.51)\end{array}$ & $\begin{array}{r}-14.17 \\
(1.52)\end{array}$ & $\begin{array}{c}-23.71 \\
(1.53)\end{array}$ & $\begin{array}{c}-13.82 \\
(1.48)\end{array}$ \\
\hline Q1 & $\begin{array}{c}-38.61 * * * \\
(4.65)\end{array}$ & $\begin{array}{l}-95.68^{* * *} \\
(19.16)\end{array}$ & $\begin{array}{c}-37.99 * * * \\
(4.59)\end{array}$ & $\begin{array}{c}-95.96^{* * *} \\
(19.28)\end{array}$ \\
\hline Q2 & $\begin{array}{c}194.66^{* * * *} \\
(23.36)\end{array}$ & $\begin{array}{l}151.28^{* * * *} \\
(30.16)\end{array}$ & $\begin{array}{l}194.81 * * * \\
(23.40)\end{array}$ & $\begin{array}{l}151.09 * * * \\
(30.17)\end{array}$ \\
\hline Q3 & $\begin{array}{c}246.64 * * * \\
(29.82)\end{array}$ & $\begin{array}{l}202.91 * * * \\
(40.76)\end{array}$ & $\begin{array}{l}246.54 * * * \\
(29.81)\end{array}$ & $\begin{array}{l}202.45^{* * * *} \\
(40.70)\end{array}$ \\
\hline LNSIZE & $\begin{array}{r}-1.62 \\
(0.58)\end{array}$ & $\begin{array}{r}-4.59 \\
(0.27)\end{array}$ & $\begin{array}{r}-2.45 \\
(0.90)\end{array}$ & $\begin{array}{r}-0.85 \\
(0.52)\end{array}$ \\
\hline LNMATURITY & $\begin{array}{c}-45.41 * * * \\
(7.30)\end{array}$ & $\begin{array}{c}5.93 \\
(1.58)\end{array}$ & $\begin{array}{l}-44.92 * * * \\
(7.21)\end{array}$ & $\begin{array}{c}6.25^{*} \\
(1.67)\end{array}$ \\
\hline LNTIMES & $\begin{array}{c}-4.36^{* *} \\
(2.16)\end{array}$ & $\begin{array}{c}-2.48^{* *} \\
(2.05)\end{array}$ & & \\
\hline LNMONTHS & & & $\begin{array}{c}-3.99 * * \\
(2.29)\end{array}$ & $\begin{array}{c}-2.44 * * \\
(2.33)\end{array}$ \\
\hline $\begin{array}{l}\operatorname{adj} R^{2} \\
F(11,2604)\end{array}$ & $\begin{array}{c}0.42 \\
172.70^{* * *}\end{array}$ & $\begin{array}{l}\text { na } \\
447.37 * * *\end{array}$ & $\begin{array}{l}0.42 \\
172.79 * * *\end{array}$ & $\begin{array}{l}\text { na } \\
448.79 * * *\end{array}$ \\
\hline
\end{tabular}

Notes: OLS represents ordinary least squares regressions. Robust regressions employ Huber iterations and biweight iterations to correct for large outliers. ${ }^{* *}$ implies significance at 1 percent; $* *$ at 5 percent; $*$ at 10 percent. Absolute values of asymptotic $t$ statistics in parentheses. 2,616 observations for all regressions. Sources: See Table 1. 
Table 3. Poisson Regressions of Guarantees on Relationship and Control Variables (dependent variable $=$ number of guarantors, count data)

\begin{tabular}{|c|c|c|c|c|}
\hline Variable & $\begin{array}{l}\quad(1) \\
\text { Parameter } \\
\text { Estimates }\end{array}$ & $\begin{array}{c}(2) \\
\text { Incidence } \\
\text { Rates }\end{array}$ & $\begin{array}{l}\text { (3) } \\
\text { Parameter } \\
\text { Estimates }\end{array}$ & $\begin{array}{c}(4) \\
\text { Incidence } \\
\text { Rates }\end{array}$ \\
\hline Intercept & $\begin{array}{l}-.004 \\
(0.20)\end{array}$ & & $\begin{array}{l}.035 \\
(0.20)\end{array}$ & \\
\hline NYC & $\begin{array}{l}.172 * * * \\
(3.39)\end{array}$ & 1.19 & $\begin{array}{l}.147 * * * \\
(2.94)\end{array}$ & 1.16 \\
\hline ALBANY & $\begin{array}{l}.127^{*} \\
(1.86)\end{array}$ & 1.14 & $\begin{array}{l}.108 \\
(1.58)\end{array}$ & 1.11 \\
\hline BOSTON & $\begin{array}{l}.125 \\
(1.16)\end{array}$ & 1.13 & $\begin{array}{c}.086 \\
(0.81)\end{array}$ & 1.09 \\
\hline RENEW & $\begin{array}{l}.033 \\
(0.36)\end{array}$ & 1.03 & $\begin{array}{l}.024 \\
(0.26)\end{array}$ & 1.02 \\
\hline Q1 & $\begin{array}{c}.034 \\
(0.69)\end{array}$ & 1.03 & $\begin{array}{c}.046 \\
(0.92)\end{array}$ & 1.05 \\
\hline Q2 & $\begin{array}{l}.081^{*} \\
(1.64)\end{array}$ & 1.08 & $\begin{array}{l}.088^{*} \\
(1.78)\end{array}$ & 1.09 \\
\hline Q3 & $\begin{array}{l}.061 \\
(1.24)\end{array}$ & 1.06 & $\begin{array}{l}.066 \\
(1.33)\end{array}$ & 1.07 \\
\hline LNSIZE & $\begin{array}{c}.009 \\
(0.56)\end{array}$ & 1.01 & $\begin{array}{l}-.001 \\
(0.09)\end{array}$ & 0.99 \\
\hline LNTERM & $\begin{array}{c}.059 \\
(1.59)\end{array}$ & 1.06 & $\begin{array}{l}.058 \\
(1.54)\end{array}$ & 1.06 \\
\hline LNTIMES & $\begin{array}{l}-.042 * * * \\
(3.60)\end{array}$ & 0.96 & -- & \\
\hline LNMONTHS & -- & & $\begin{array}{l}-.022 * * \\
(2.20)\end{array}$ & \\
\hline $\begin{array}{l}\text { pseudo } \mathrm{R}^{2} \\
\text { goodness of fit } \mathrm{P}^{2} \\
\text { model } \mathrm{P}^{2}\end{array}$ & $\begin{array}{l}.04 \\
899.99 * * * \\
27.63 * * *\end{array}$ & & $\begin{array}{l}.035 \\
908.14 * * * \\
19.49 * *\end{array}$ & \\
\hline
\end{tabular}

Notes: $* * *$ implies significance at 1 percent; $* *$ at 5 percent; $*$ at 10 percent. 2,616 observations for all regressions. The incidence rate ratios for a ) $x_{i}$ change in $x_{i}$ equals $\left[\exp \left(\$_{i}\right) x_{i}\right)$ ]. The incidence rate of 1.19 for NYC variable in column (2) implies that the bank demanded 1.19 times the number of endorsers for notes payable in New York City compared to locally payable loans, holding all else constant. Other incidence rate ratios are interpreted similarly.

Sources: See Table 1. 
Table 4. Probit Regressions of Loan Renegotiation on Relationship and Control Variables

\begin{tabular}{|c|c|c|c|c|}
\hline Variable & $\begin{array}{c}\text { (1) } \\
\text { Parameter } \\
\text { Estimates }\end{array}$ & $\stackrel{(2)}{M / M}$ & $\begin{array}{l}\text { (3) } \\
\text { Parameter } \\
\text { Estimates }\end{array}$ & $\begin{array}{c}(4) \\
M / M\end{array}$ \\
\hline Intercept & $\begin{array}{l}-4.076^{* * *} \\
(3.22)\end{array}$ & & $\begin{array}{l}-4.430^{* * * *} \\
(3.39)\end{array}$ & \\
\hline NYC & $\begin{array}{l}-.500^{*} \\
(1.62)\end{array}$ & -.051 & $\begin{array}{l}-.482 \\
(1.56)\end{array}$ & -.034 \\
\hline ALBANY & $\begin{array}{l}-.315 \\
(1.06)\end{array}$ & -.033 & $\begin{array}{l}-.347 \\
(1.15)\end{array}$ & -.024 \\
\hline Q3 & $\begin{array}{l}.157 \\
(0.87)\end{array}$ & .019 & $\begin{array}{l}.164 \\
(0.89)\end{array}$ & .021 \\
\hline GUARANTEE & $\begin{array}{l}-.182 \\
(1.29)\end{array}$ & -.023 & $\begin{array}{l}-.116 \\
(0.83)\end{array}$ & -.017 \\
\hline LNAMT & $\begin{array}{l}.021 \\
(0.27)\end{array}$ & .003 & $\begin{array}{c}.027 \\
(0.35)\end{array}$ & .004 \\
\hline LNTERM & $\begin{array}{l}.628 * * \\
(2.41)\end{array}$ & .078 & $\begin{array}{l}.593 * * \\
(2.24)\end{array}$ & .058 \\
\hline LNTIMES & $\begin{array}{l}.056 \\
(0.91)\end{array}$ & .007 & & \\
\hline LNMONTHS & & & $\begin{array}{l}.157 * * \\
(2.48)\end{array}$ & .016 \\
\hline pseudo $\mathrm{R}^{2}$ & .06 & & .08 & \\
\hline $\mathrm{P}^{2}$ & $17.9 * *$ & & $23.8 * * *$ & \\
\hline log-likelihood & -131.9 & & -129.0 & \\
\hline
\end{tabular}

Notes: Dependent variable is dichotomous and equal to 1 if bank renewed/renegotiated a loan maturing during the financial panic in autumn 1857. Numbers in parentheses are absolute values of $\mathrm{z}$ statistics. ${ }^{* * *}$ implies significant at 1 percent; $* *$ at 5 percent; $*$ at 10 percent. There are 519 observations in both regressions.

Source: Black River Bank Records, Discount Books 2 and 3. 